Economia e Sociedade, Campinas, Unicamp. IE. http://dx.doi.org/10.1590/1982-3533.2020v30n1art02

\title{
Dinheiro como relação social: uma leitura do poder monetário do Estado na MMT *
}

\author{
Edemilson Paraná **,**** \\ Maria de Lourdes Rollemberg Mollo ${ }^{* * * *}$
}

\begin{abstract}
Resumo
Este artigo discute as seguintes ideias propostas pela Modern Money Theory (MMT): i) o postulado da moeda como uma criatura do Estado; ii) de que o crescimento econômico pode ser obtido por meio de déficits fiscais; e iii) de que a ação do Estado pode possibilitar o alcance do pleno emprego. Tais ideias implicam significativo papel monetário do Estado, papel que avaliamos à luz de uma concepção marxista do dinheiro como relação social. Destacamos o poder hierarquicamente superior do Estado nesse particular, mas também seus limites, apontando algumas barreiras à aplicação das prescrições da MMT. De um lado, demonstramos que podem haver efeitos substantivos das políticas fiscal e monetária sobre a produção real; por outro, problematizamos a noção de pleno emprego à luz dos limites impostos pelas lutas de classe ao papel do Estado como empregador em última instância.
\end{abstract}

Palavras-chave: Dinheiro, Estado, Poder, Modern Money Theory (MMT), Pleno Emprego.

\begin{abstract}
Money as a social relation: an analysis of the monetary power of the State in the MMT

This article discusses the following ideas proposed by the Modern Money Theory (MMT): i) the postulate of money as a creature of the state; ii) that economic growth can be achieved through fiscal deficits; and iii) that the state action can enable the attainment of full employment. Such ideas imply a significant monetary role carried out by the state, a role that is evaluated here in light of a Marxist conception of money as a social relation. We emphasize the hierarchically superior power of the state in this regard, but also its limits, highlighting some barriers to the application of MMT prescriptions. On the one hand, we show that there can be substantive effects of fiscal and monetary policies on real production; on the other hand, we problematize the notion of full employment in light of the limits imposed by class struggles on the role of the state as the employer of last resort.
\end{abstract}

Keywords: Money, State, Power, Modern Money Theory (MMT), Full employment.

JEL B50, E11, E12.

\section{Introdução}

O debate econômico heterodoxo ganha força em momentos de crise, como o que vivemos, quando o ruir das certezas ortodoxas dominantes exige que se ouça opiniões distintas. Assim vem sendo com os debates em torno da Modern Monetary Theory (MMT). Baseada em ideias heterodoxas de Keynes (1996), Aba Lerner (1943, 1947) e Minsky (1986), tem um representante importante na figura de Randal Wray (1998), que vem há muito retomando a tese cartalista de moeda para propor

\footnotetext{
${ }^{*}$ Artigo recebido em 28 de maio de 2019 e aprovado em 20 de julho de 2020.

${ }^{* *}$ Pseudônimo de Edemilson Cruz Santana Junior.

${ }^{* * *}$ Professor do Departamento de Ciências Sociais da Universidade Federal do Ceará (UFC), Fortaleza, CE, Brasil. E-mail: edemilsonparana@gmail.com. ORCiD: https://orcid.org/0000-0003-3487-9677.

${ }^{* * * *}$ Professora do Departamento de Economia da Universidade de Brasília (UnB), Brasília, DF, Brasil. E-mail: mlmollo@ unb.br. ORCiD: http://orcid.org/0000-0002-4303-6914.
} 
alternativas à visão econômica dominante. Seu ressurgimento neste momento se deve, nos Estados Unidos, à crítica ao neoliberalismo vocalizada, em especial, pela pré-candidatura do senador Bernie Sanders à presidência do país. No Brasil, a abordagem ganha atenção renovada a partir da intervenção recente de André Lara Resende (2019a, 2019b) ${ }^{1}$, que passa a apresenta-la como alternativa aos equívocos por ele observados na teoria macroeconômica dominante ${ }^{2}$.

É, de certo modo, bem-vinda, nesse quadro, a retomada do debate de algumas importantes proposições como, por exemplo: do crescimento estimulado pela demanda, de que déficits públicos não são automaticamente problemáticos - em contraposição ao neoliberalismo ortodoxo e suas prescrições de austeridade. Por isso, cumpre bem discuti-las para melhor apreendermos as potencialidades e os limites das políticas econômicas alternativas propostas por essa abordagem.

Interessa discutir, aqui, em particular, algumas ideias basilares defendidas pela MMT. Primeiro, o postulado da moeda como uma criatura do Estado - quando este a requer como pagamento de tributos e com ela financia seus gastos. Segundo, que "given usual private sector preferences regarding net saving, economic growth requires persistent government deficits" (Wray, 1998, p. 75). Terceiro, que o Estado pode e deve manter um estoque regulador de emprego para garantir o pleno emprego, entendido como o emprego de todos que desejem trabalhar por um salário fixado pelo programa governamental. Como é possível perceber, essas ideias implicam um significativo papel monetário do Estado na garantia da geração de emprego e renda, papel que nos interessa discutir a partir da definição de dinheiro como relação social, herdada de uma concepção não-substancialista do dinheiro em Marx (Paraná, 2020, p. 228-238). A discussão proposta neste artigo está baseada, ademais, nas formulações de Suzanne de Brunhoff, autora com vasta e reconhecida contribuição tanto sobre dinheiro $(1977,1978 \mathrm{a}, 1978 \mathrm{~b}, 1979)$ quanto sobre o Estado e seu papel na gestão monetária (1978a, 1985, 1991).

Para isso, o artigo está organizado em mais quatro seções além desta Introdução. Na primeira, tratamos da concepção de dinheiro como relação social. A segunda seção trata do alcance do poder monetário do Estado à luz da visão precedente. A ideia aqui é destacar o poder hierarquicamente superior do Estado em matéria monetária, mas também os limites deste poder, tanto no que se refere à política econômica em geral quanto à gestão especificamente monetária, comparando tais avaliações com as visões da MMT. A terceira seção visa melhor discutir a referida noção de dinheiro em relação aos limites impostos à aplicação das prescrições da MMT - tanto à moeda internacional quanto às periféricas, como a brasileira, tendo em vista o papel monetário do Estado e a hierarquia entre as moedas. Adicionalmente, problematiza a noção de pleno emprego nas visões da MMT à luz dos limites impostos pelas lutas de classe ao papel do Estado como empregador em última instância.

\section{$1 \mathrm{O}$ dinheiro como relação social no mundo das mercadorias}

A primeira divergência entre a MMT e a concepção não-substancialista de dinheiro como relação social em Marx está no fato de que, embora se possa encontrá-lo historicamente em vários

(1) Estes e outros textos recentes do autor foram posteriormente reunidos em Resende (2020).

(2) Embora não seja propriamente um integrante da MMT, Resende (2019a, 2019b) vem defendendo algumas de suas teses. Segundo ele, a MMT, vista como novo paradigma, teria quatro pilares: a) a moeda é essencialmente uma unidade de conta; b) o governo que a emite não tem restrições financeiras; c) o Banco Central fixa a taxa de juros que determina o custo da dívida; e d) se a taxa de juros for inferior à taxa de crescimento da economia, a relação dívida/PIB decresce sem aumento da carga tributária. 
modos de produção, desde a Antiguidade, o dinheiro se transforma e ganha importância e papel diferenciados no capitalismo - em função do valor e dele mesmo se constituírem como relações sociais gerais neste tipo de economia ${ }^{3}$.

Para a MMT, a origem do dinheiro está "more specifically in tax debt that is levied in money form" (Wray, 1998, p. 69). Mesmo que não se saiba ao certo qual é a origem histórica deste, segundo a MMT, o que importa é que nas economias modernas o governo cria dinheiro para financiar suas compras e esse dinheiro paga os tributos. Segundo Wray (1998, p. 80),

the government first spends fiat money (to purchase goods, services and assets or to provide 'transfer payments', which retires a government liability)...Thus taxes cannot be paid until actual coins or notes are injected into the economy, or bank reserves have been created. Government expenditure will generate coins, notes or bank reserves that are needed to 'pay taxes'.

Ou seja, os gastos do governo criam a moeda necessária para pagar os impostos, o que faz da moeda, lógica e historicamente, uma criatura do Estado e não do mercado. Caso haja uma retenção de dinheiro ${ }^{4}$ desejada pelo público, é preciso que o governo compense com déficit ou a economia entra em um processo deflacionário. Temos, pois, uma moeda que é criação apenas do Estado e por ele controlada para regular a marcha dos negócios. Ou seja, como um Estado soberano é aquele que cria sua própria moeda, este "is not financially constrained in the way that non-sovereign units are, so that it can focus on issues such as full-employment and price stability" (Tymoigne; Wray, 2013, p. 2). Não apenas ele pode emitir sua própria moeda para fazer face a seus compromissos em sua unidade de conta, "but any self-imposed constraint on their budgetary operations can be by-passed by changed rules".

Na perspectiva marxista, como sabemos, o dinheiro é a manifestação por excelência do valor e, por isso, do capital. Aparece, assim, como fundamental para a operacionalização da dinâmica sistêmica do capitalismo, na medida em que é a partir dele que se inicia o processo produtivo, com a compra de força de trabalho e de meios de produção. É também apenas por meio dele que as classes sociais são inseridas nessa mesma dinâmica, sendo a forma pela qual são pagos os salários, lucros, rendas e juros. É ainda o veículo de realização de lucros e do consumo, bem como do reinvestimento e do crédito, que possibilitam a ampliação da capacidade produtiva. O ciclo do capital é, em suma, "dinheiro que se valoriza".

$\mathrm{Na}$ frase que abre $O$ Capital $I$, Marx aponta que "a riqueza das sociedades onde reina o modo de produção capitalista aparece como uma 'enorme coleção de mercadorias"” (Marx, 2013, p. 113).

(3) Distintamente do mainstream em economia, tanto a análise de Marx quanto a da heterodoxia keynesiana conferem ao dinheiro importância analítica significativa, uma vez que, nestas, ele não é neutro - como nas acepções ortodoxas - e, neste sentido, pode afetar, e afeta, de maneira duradoura, a atividade produtiva. Há também, nessas visões (marxista e keynesiana heterodoxa), argumentos que demostram que o dinheiro pode ser desejado por ele mesmo, para apropriação privada, o que é outra forma de apreender sua importância social. Essa é, inclusive, uma das razões pelas quais o dinheiro é considerado endógeno, ou seja, embora possa sofrer e sofra intervenção das autoridades monetárias, estas não têm o controle pleno de sua circulação ou da dinâmica monetária. Apesar de sua raiz keynesiana, a MMT, como veremos, trata a moeda de modo um pouco diferente; embora fuja do escopo deste artigo analisar em detalhe tais distinções.

(4) Essa retenção de dinheiro que Wray chama de poupança líquida, é a preferência pela liquidez keynesiana. Optamos aqui por chamar de preferência pela liquidez porque o próprio Keynes e a heterodoxia pós-keynesiana em geral, inclusive Minsky, assim o fazem, e porque para Keynes a poupança não tem importância analítica, uma vez que não é necessária para o finance; surge necessariamente como resultado do investimento, em proporção a ele; e mesmo que seja a fonte do funding, só o viabilizará se a preferência pela liquidez dos poupadores não obstá-lo. Ver a esse respeito Keynes (1983a, 1983b). 
Essas mercadorias, explica o autor, são produzidas por meio de processos de trabalho que, em tal modo de produção, implicam uma contradição fundamental: são ao mesmo tempo privados e sociais. Privados porque realizados por produtores separados e aparentemente independentes entre si; sociais porque mobilizados na produção de mercadorias cujo objetivo é a venda, por meio da qual se realiza a divisão social do trabalho que, desse modo, torna tais trabalhos particulares dependentes socialmente uns dos outros. Faz-se necessário, então, um mecanismo capaz de "resolver" de alguma forma, ainda que movimentando-a no tempo e espaço, tal contradição constitutiva. Esse mecanismo é o valor de troca, representado socialmente no dinheiro - o objeto de nossa reflexão. A "resolução" das mercadorias em tela não é outra coisa senão a resolução da contradição privado-social constitutiva do trabalho sob o capitalismo 5 .

Isso posto, fica evidente que o dinheiro é a forma de aparecimento, ou a representação social do valor como tempo de trabalho socialmente necessário à produção das mercadorias. É precisamente ao ser trocado por dinheiro que o trabalho privado ou particular pode adquirir caráter universal ${ }^{6}$.

Portanto, para realizar a mercadoria de um só golpe em valor de troca e lhe conferir a eficiência universal do valor de troca, não é suficiente a troca por uma mercadoria particular. A mercadoria deve ser trocada por uma terceira coisa que, por sua vez, não seja ela mesma uma mercadoria particular, mas o símbolo da mercadoria como mercadoria, o próprio valor de troca da mercadoria; portanto, que represente, digamos o tempo de trabalho enquanto tal, digamos um pedaço de papel ou de couro que represente uma parte alíquota de tempo de trabalho. (Um tal símbolo presume o reconhecimento universal; só pode ser um símbolo social; expressa de fato apenas uma relação social) (Marx, 2011, p. 94, itálicos do autor, negritos nossos).

O dinheiro é, assim, um "validador social das mercadorias ou dos trabalhos privados nelas contidos" (Mollo, 2010, p. 128), assumindo, desta maneira, uma forma existente de unidade de todas as mercadorias, de modo a possibilitar seu nexo sistêmico. É por meio do dinheiro que se objetiva, então, a divisão social do trabalho como processo ratificado pela troca de mercadorias. É nesse momento, e por meio desse mecanismo, que trabalhos privados, aparentemente independentes, se fazem sociais, movimentando no tempo a contradição privado-social característica dos processos de trabalho.

Mas cabe recordarmos que a contradição privado-social característica dos processos de trabalho no capitalismo é tributária ela mesma de outra contradição: aquela existente entre valor de uso e valor das mercadorias. Sabe-se que a mercadoria contém, ao mesmo tempo, dois atributos: valor de uso e valor - sendo o valor de troca sua forma de expressão social. No entanto, para que opere como valor de troca, a mercadoria tem de aparecer como um não-valor de uso para o seu proprietário. É precisamente com a troca por meio do dinheiro que esse impasse se "resolve". Isso se dá justamente porque o dinheiro assume, nas economias mercantis, o papel de representante universal do valor de

(5) No entanto, "resolver a contradição privado-social não a elimina, mas permite que, apesar da sua existência, a sociedade produtora de mercadorias não possa ser vista como um caos. Há conexão, há a possibilidade efetiva de funcionamento, porque a divisão social do trabalho se faz. Ou seja, há uma forma de fazer a equivalência das mercadorias, de dividir tarefas e distribuir produtos do trabalho nesta sociedade, mesmo que de forma complexa e indireta, por meio de um terceiro, o dinheiro, que é o equivalente geral" (Mollo, 2010, p. 119, grifo da autora).

(6) Ou seja, o "caráter social do trabalho" aparece "como a existência monetária da mercadoria" (Marx, 2017, p. 574, grifo do autor). 
troca e de todo tipo de riqueza, valor por excelência, encarnação do trabalho, ou equivalente universal - o que permite, desta forma, que a circulação das mercadorias transcorra. O dinheiro é para Marx, então, um dispositivo de organização social em sociedades mercantis, que surge (em termos lógicos) para resolver a antítese contida na mercadoria entre valor de uso e valor.

É isso, pois, que possibilita ao dinheiro cristalizar enorme poder social como "penhor mobiliário da sociedade", caracterizando, em vista de sua "propriedade social simbólica" (Marx, 1980, p. 96), o estranhamento típico de "uma relação social determinada entre os próprios homens que aqui assume, para eles, a forma fantasmagórica de uma relação entre coisas" (Marx, 2013, p. 147). Desse modo, "a potência social torna-se potência da pessoa privada" (Marx, 2013, p. 206) ${ }^{7}$.

É necessário frisar que Marx não está analisando aqui outra coisa senão as relações entre dinheiro e mercadoria existentes no capitalismo $^{8}$, o mesmo se aplicando, naturalmente, à própria forma valor". Assim, sobre o que seria uma origem ou "gênese" do dinheiro,

it is clear that with the phrase "origin" (Genesis) he [Marx] does not mean the historical emergence of money, but rather a conceptual relationship of development. He is not concerned with the historical development of money (not even in a completely abstract sense) but with a conceptual reconstruction of the connection between the "simple form of value" (a commodity expressing its value through another commodity) and the "money form" (Heinrich, 2004, p. 56, grifos do autor).

Se é certo que Marx analisa a mercadoria e o dinheiro realmente existentes no capitalismo, a "gênese analítica" revela um movimento ou processo de desenvolvimento de uma forma social: o dinheiro é produto das necessidades fundamentais de qualquer economia mercantil, desenvolvendose com a mercadoria e através dela. Em uma sociedade produtora de mercadorias, onde figura a divisão social do trabalho, o dinheiro surge como uma necessidade incontornável para a generalização das trocas, e não apenas como uma mera "ajuda prática" a facilitá-las ${ }^{10}$. Ainda que se modifique e que surjam formas de práticas monetárias distintas ao longo do tempo, como é de fato o caso, o dinheiro é uma relação social basilar em economias mercantis e, deste modo, algo inseparável e constitutivo de sua lógica sistêmica de funcionamento. Mas, também aqui, "a economia mercantil é investigada como uma dimensão do capitalismo" (Belluzzo, 2013, p. 8), e não como algo apartado

(7) “A dependência recíproca e multilateral dos indivíduos mutuamente indiferentes forma sua conexão social. Essa conexão social é expressa no valor de troca, e somente nele a atividade própria ou o produto de cada indivíduo devêm uma atividade ou produto para si; o indivíduo tem de produzir um produto universal - o valor de troca, ou esse último por si isolado, individualizado, dinheiro. De outro lado, o poder que cada indivíduo exerce sobre a atividade dos outros ou sobre as riquezas sociais existe nele como o proprietário de valores de troca, de dinheiro. Seu poder social, assim como seu nexo com a sociedade, [o indivíduo] traz consigo no bolso" (Marx, 2011, p. 105, grifos nossos).

(8) Sem a generalização das relações mercantis, monetárias e capitalistas e constituição das forças produtivas não há trabalho abstrato e, portanto, a reprodução da riqueza social não pode estar submetida à forma valor (Belluzzo, 2013, p. 64, grifos do autor).

(9) "O conceito econômico do valor não ocorre entre os antigos... O conceito de valor pertence completamente à economia mais moderna, porque é a expressão mais abstrata do próprio capital e da produção baseada nele. No conceito de valor é revelado seu segredo" (Marx, 2011, p. 651). Ou ainda: "A forma de valor do produto do trabalho é a forma mais abstrata, mas também mais geral do modo burguês de produção, que assim se caracteriza como um tipo particular de produção social e, ao mesmo tempo, um tipo histórico” (Marx, 2013, p. 155).

(10) "So money is in no way merely a helpful means of simplifying exchange on the practical level and an appendage of value theory on the theoretical level. [...] without the value form, commodities cannot be related to one another as values, and only with the money form does an adequate form of value exist" (Heinrich, 2004, p. 63-64). 
ou precedente teórica, lógica ou historicamente desse. Antes de mais nada, é o modo de produção capitalista que emerge como o objeto teórico central da análise marxiana.

Em virtude desses fatos, se o dinheiro, para Marx, com as determinações com as quais hoje o conhecemos, nasce com a produção de mercadorias e com ela se desenvolve, isto requer, conforme recorda Brunhoff (1978a), seguindo neste particular Rubin (1987), que se analise concomitantemente a relação do dinheiro com o caráter mercantil da economia capitalista por um lado, e sua articulação com o caráter capitalista propriamente dito do trabalho assalariado, por outro.

Sabe-se, na perspectiva marxiana, que o traço definidor de um processo de produção como capitalista é a exploração do trabalho assalariado - capaz de extrair-lhe mais-valia. É por meio da mais-valia, gerada pelos trabalhadores e apropriada pelos capitalistas, de acordo com tal perspectiva, que são socialmente inseridas ambas as classes na lógica de funcionamento do sistema. Para isso, entretanto, é fundamental que a força de trabalho seja transformada em mercadoria e, deste modo, em dinheiro (por meio de contratos salariais que são monetários). É precisamente a transformação da força de trabalho em mercadoria, sabemos, que abre a possibilidade de esta ser vendida e, então, utilizada para gerar valor - algo que só pode ocorrer, na constituição relacional das classes sociais, por meio da negação da posse dos meios de produção aos trabalhadores, acompanhada da apropriação privada destes meios de produção pelos capitalistas.

Confirmada a venda da força de trabalho como mercadoria, observa-se a inserção social do trabalhador, e o dinheiro como relação social. Comprada a força de trabalho pelo seu valor, e tendo ela produzido um valor monetário maior do que este (mais-valia, convertida em dinheiro), insere-se socialmente o capitalista - cujo objetivo é o lucro e a acumulação de capital que o sustenta. É por isso que, para Marx, a economia real é necessariamente monetária e a teoria do valor não é antes senão uma teoria monetária do valor (Heinrich, 2004, p. 63-64).

Ocorre que o dinheiro só pode funcionar como um fim em si mesmo (D-M-D') quando funciona como capital-dinheiro, implementando a relação de capital ao comprar a força de trabalho. A exploração da força de trabalho na esfera da produção constitui o pressuposto para essa incorporação e esse movimento. A venda das mercadorias produzidas com valor maior do que o colocado no início leva ao capital - dinheiro que se valoriza. Disso resulta que valor e dinheiro são conceitos que não podem ser completamente definidos independentemente da noção de capital. Ambos contêm e estão contidos no conceito de capital. Sendo uma teoria monetária do valor, a teoria do valor de Marx é, ao mesmo tempo, uma teoria monetária do capital (Milios, 2009, p. 266).

Aparece aqui uma disjuntiva também reveladora, novamente, do caráter histórico-contingente da relação capital-dinheiro. Para que o dinheiro adquira a qualidade de capital, é preciso que a totalidade do processo social de reprodução material seja mediado pela mercadoria e pelo dinheiro, não estando restrito a um nicho ou região no interior de um modo de produção (pensemos no período feudal, na Europa ocidental, por exemplo). Mas, por outro lado, a generalização da produção de mercadorias é somente possível quando a própria produção é transformada em produção capitalista, quando o aumento da riqueza abstrata se torna o fim imediato da produção - submetendo todas as demais relações sociais a este objetivo. 
O dinheiro atua, então, validando socialmente os trabalhos privados em uma dinâmica tal em que o valor das mercadorias não é determinado apenas ou previamente na produção, mas a posteriori ou, nas palavras de Marx, "post festum"11. Não estando assegurada a compatibilidade entre a produção e a circulação, nos deparamos com um processo complexo (e sujeito a inúmeras intempéries) de determinação do valor. O tempo de trabalho a ser levado em consideração é apenas aquele de fato "socialmente necessário", o "tempo de trabalho em média necessário" (Marx, 2013, p. 117). O valor da mercadoria determinada pelo tempo de trabalho gasto na sua produção é apenas seu valor "médio".

Quando os vários ramos da economia são concebidos em conjunto, as condições médias de produção implicam preços de produção nos quais estão embutidos as taxas de lucro médias, com os preços de mercado flutuando, então, em torno deles (Marx, 2017). Finalmente, as flutuações na oferta e na demanda, dentre outras complexidades, fazem com que os preços de mercado sempre se diferenciem destes preços de produção (sendo justamente tal complexidade e flutuações dos preços aquilo que garante sua funcionalidade como mecanismo de coordenação da economia de mercado capitalista). É por isso que, ao invés de ser determinada antecipadamente, a validação social das mercadorias, o caráter social de sua produção, só pode se dar a posteriori, por meio do constante "tateamento" entre valores e preços (Brunhoff, 1978a).

Eis que se torna, uma vez mais, evidente a necessidade, para isso, de um terceiro, exterior à mercadoria, o dinheiro, eleito socialmente como espelho do valor. A falta de uma proporcionalidade segura entre produção e distribuição, ou seja, a falta de garantia de compatibilidade ou consistência a priori entre ambas, lega ao dinheiro e às relações monetárias enorme importância no estabelecimento dos valores e preços - um processo de tal modo oscilante que jamais pode ser caracterizado como qualquer tipo de "equilíbrio".

Em suma, o valor de troca, a forma valor e o dinheiro como forma universal do valor emergem de processos socialmente determinados de produção e circulação, aparecendo como resultado de um conjunto de relações sociais características, ao mesmo tempo, da troca de mercadorias e do processo capitalista de produção. Sem levar em consideração essa determinação, a forma valor não pode aparecer e se tornar a forma social dominante nas sociedades onde impera o modo de produção capitalista. Esse caráter social aparece, ademais, quando o dinheiro surge (ou é gerado) a partir de um processo igualmente social de "eleição", "exclusão" e reconhecimento de uma mercadoria para cumprir o papel de equivalente geral. Neste sentido, o dinheiro não precisa ser uma mercadoria "produzida", mas precisa, sim, ser uma criação social ${ }^{12}$.

Tal criação social implica o Estado, como parte da sociedade, mas implica também, logicamente, a sociedade como um todo, em seu conjunto. Assim, embora o Estado configure um poder hierarquicamente superior em relação a outros agentes, não é sempre capaz de controlar os efeitos sobre a dinâmica monetária que decorrem da ação dos demais participantes da sociedade, como parecem ignorar os teóricos da MMT. É o que veremos na próxima seção.

(11) O “caráter social da produção só é posto post festum, pela ascensão dos produtos a valores de troca e pela troca destes valores de troca" (Marx, 2011, p. 119).

(12) Daí a afirmação de Heinrich (2004, p. 70), de que quando o sistema de crédito é levado em consideração, “does it become clear that the existence of a money commodity is merely a historically transitional state of affairs, but does not correspond to 'the capitalist mode of production, in its ideal average' that Marx sought to analyze". 


\section{$2 \mathrm{O}$ alcance do poder monetário do Estado}

Intervindo no debate acerca da necessidade do Estado ${ }^{13}$ e de sua autonomia (relativa) em relação à sociedade, a partir de Marx, Suzanne de Brunhoff (1985) afirma que o Estado é ao mesmo tempo condição e resultado do processo capitalista de produção. Ecoando, nesse particular, o resgate althusseriano de Engels, a autora destaca (1978a, p. 14) que, no quadro de uma sociedade dividida em classes, o Estado é caracterizado, ao mesmo tempo, por uma "exterioridade", algo que o situa "acima da sociedade", e por uma "imanência", relacionada ao importante papel econômico que tem a cumprir. É essa "posição contraditória" - e os dois termos dessa contradição só têm sentido, naturalmente, na relação que estabelecem entre si - que sustenta a autonomia relativa do Estado frente à acumulação de capital.

Da concepção de Estado aqui exposta por Marx, pode-se reter que não existe um Estado que tenha, entre outras tarefas, uma "função econômica", mas que imanência e exterioridade estão ligadas e que o efeito destas depende de condições objetivas, graças às quais se constitui um "conjunto sistemático" de práticas estatais. Sem estas condições, o "poder do Estado"... nada pode (Brunhoff, 1978a, p. 16).

A ação do Estado, ao mesmo tempo imanente e não redutível à relação fundamental de exploração, pode ser melhor captada, sustenta a autora, por meio da consideração das particularidades das mercadorias consideradas "especiais" no modo de produção capitalista, a ser, a força de trabalho e a moeda. Isso se deve ao fato de tais mercadorias especiais - dada a relação particular que nelas se estabelece entre valor de uso e valor de troca - exigirem intervenção (gestão/sanção) do Estado para sua reprodução continuada.

A gestão estatal da mercadoria particular que é a força de trabalho (inseparável do aprovisionamento contínuo de mão-de-obra barata M), a gestão estatal da moeda (ligada à acumulação de capital-dinheiro D), tais são os principais eixos de uma ação do Estado, indissociável da produção e da circulação capitalistas em geral (Brunhoff, 1985, p. 3).

Adentrando à análise da ação do Estado quanto ao dinheiro, cumpre resgatarmos a ideia de que o dinheiro como equivalente geral, validador social de trabalhos privados, e responsável pela inserção social das classes, tem um caráter social que não pode ficar sujeito a interesses privados. Daí a necessidade do Estado na gestão monetária.

O Estado tem um papel hierarquicamente superior, dado seu caráter público, o que lhe permite intervir nas dinâmicas monetárias, mas esse papel é limitado no sentido de que não pode controlar plenamente a dinâmica social da qual faz parte. O Estado, portanto, não se confunde com essa dinâmica, que envolve a sociedade como um todo, embora dela participe, e não pode, por isso, controlá-la in toto. A despeito dessa limitação, o Estado, sim, desempenha um papel importante no processo complexo de reprodução do equivalente geral, que implica a imposição de normas, leis, regulamentos, práticas e acordos formais de natureza econômica e política. Trata-se, assim, de uma “ação estatal simultaneamente exterior e imanente à circulação do capital. A intervenção do Estado

(13) Para uma caracterização geral do Estado nas obras de Marx bem como o desenvolvimento dessas ideias em autores marxistas posteriores, ver Paraná (2020, p. 265-281). 
não cria a forma moeda, que se constitui na circulação mercantil, mas contribui para determiná-la como tal" (Brunhoff, 1985, p. 39).

Ele [o Estado] participa do movimento das contradições desde a circulação das mercadorias. Sem ele, não haveria fixação de um padrão dos preços como unidade de medidas; não haveria cunhagem do ouro em moedas que circulam no âmbito de um dado país; não haveria garantia da validade dos signos de ouro utilizados como meios de circulação; não haveria formação de uma moeda nacional a ser trocada por moedas estrangeiras. A ação monetária do Estado tem um duplo caráter: ratifica certas contradições do equivalente geral, disfarçando o papel determinante do valor de troca e validando práticas monetárias diversificadas (cunhagem de moedas de ouro, emissão de cédulas eventualmente não conversíveis em ouro). Mas, por outro lado, ela contribui para a necessária articulação das formas e das funções da moeda (Brunhoff, 1978a, p. 61-62).

É, como se disse, o poder hierarquicamente superior do Estado que lhe permite cumprir tais funções. À cunhagem, entesouramento e relativo controle da circulação do dinheiro corresponde o estabelecimento de um poder geral e uniforme do Estado sobre o conjunto do território nacional. Como gerente central do dinheiro, o Estado é levado a administrá-lo em relação a sua reprodução como equivalente geral. Assim, a intervenção estatal no que se refere ao dinheiro,

tem como pressuposto a existência de uma coerção, qual seja, o uso de uma moeda que deve a todo instante ser aceita como meio de pagamento estável e válido no país e no plano internacional. Esta coerção não é outra que não a do invariante-equivalente geral (padrão, meio de circulação, meio de reserva, meio de pagamento) (Brunhoff, 1978a, p. 13).

A apropriação de dinheiro é, além disso, uma fonte de poder político, já que o poder do equivalente geral configura uma alavanca material sempre mobilizável, conversível em qualquer mercadoria (e o poder criador de dinheiro do Estado é, neste sentido, certamente muito importante em termos econômico e político). É o poder social do dinheiro, como equivalente geral e valor por excelência que justifica, para Marx, que ele possa ser desejado como tesouro em determinadas ocasiões, em que "o poder social torna-se o poder privado de particulares" (Brunhoff, 1978b, p. 46). Nestas circunstâncias, a existência do entesouramento afirma o reconhecimento social do dinheiro, sua aceitação social para cumprir tal papel de equivalente geral e "representante universal da riqueza material", mesmo quando inconversível.

Diante disso, "o poder monetário do Estado é necessariamente limitado pelo poder social que a moeda dá aos particulares que entesouram" (Brunhoff, 1978b, p. 46). A injeção ou retirada de dinheiro em circulação pelas autoridades monetárias pode ser contrabalançada pelo entesouramento ou desentesouramento por parte do setor privado, o que limita o controle sobre a circulação monetária, tornando endógena a circulação e a dinâmica monetárias. É isso o que leva Marx a sustentar que a função meio de entesouramento funciona como "canal adutor" da circulação ${ }^{14}$.

(14) Observe-se que se, por um lado, o entesouramento explicita o reconhecimento social do dinheiro como equivalente geral e, por outro, a retirada de dinheiro da circulação como tesouro, impede as compras e vendas que permeiam o processo de acumulação. Isso explicita que as várias funções monetárias, ainda que contraditórias entre si, precisam ser todas cumpridas para que o processo de acumulação possa fluir. Isso requer que o dinheiro seja desejado por alguns agentes em uma função, enquanto outros o requeiram nas demais. A polarização em uma de suas funções é indício de crise: deflação, por exemplo, quando a demanda se polariza como meio de entesouramento; inflação, quando a polarização se dá como meio de circulação. 
O poder de um Estado nacional, por sua vez, é também limitado pelo poder dos demais Estados, ou seja, "o entesouramento público de uma nação significa que o poder monetário de um Estado é limitado pelo dos outros Estados. Os efeitos políticos e sociais da moeda são dependentes de sua natureza econômica, como expressão de uma divisão da sociedade em agentes econômicos autônomos" (Brunhoff,1978b, p. 46-47).

Isso posto, não tendo o dinheiro um valor intrínseco, a validação social das mercadorias e a lei do valor se impõem, então, seja ao dinheiro (como equivalente geral) seja às mercadorias, em última instância, por meio da operação denominada por Brunhoff (1978a) de restrição monetária, ou coerção monetária ("contrainte monétaire"), qual seja: i) a necessidade de que toda mercadoria seja convertida em dinheiro, ii) de que toda forma de dinheiro seja ao fim convertida em equivalente geral, iii) e a necessidade de que o equivalente geral, ele mesmo, se reproduza como tal. Neste processo, a questão do papel monetário do Estado e seus limites é particularmente importante. Vejamos.

Quando a moeda é criada pelo sistema bancário ela entra na circulação antecipando a validação social dos trabalhos privados contidos nas mercadorias adquiridas, já que os bancos são entidades privadas e não podem validar socialmente de forma definitiva tal conteúdo social. Quando o Estado garante a moeda bancária, assegura a conversibilidade das moedas bancárias em moeda nacional. Mas os conteúdos de trabalho privados são apenas "pseudo-validados", uma vez que a sociedade ainda não se manifestou (por meio da compra/venda das mercadorias no mercado) quanto ao seu caráter socialmente necessário. É preciso que a dinâmica monetária como um todo continue a funcionar para que essa validação social se complete.

É preciso também que o Estado nacional assegure a conversibilidade da moeda nacional em moeda internacional - algo necessário, mas nem sempre garantido. Neste processo, a autoridade monetária tateia, por exemplo, entre, por um lado, prover dinheiro suficiente para garantir a acumulação do capital e a validação social dos trabalhos privados envolvidos, e para garantir a conversibilidade das moedas bancárias, privadas, e, por outro, evitar o exagero que levaria à perda do reconhecimento (social) da moeda via inflação. As inflações e crises cambiais, neste sentido, são indícios que não fazem mais do que expressar as dificuldades impostas para o cumprimento da restrição monetária e para a validação social das mercadorias em geral, e refletem, desta forma, os limites do papel e do poder monetário do Estado.

Tanto as inflações, quanto as crises cambiais, nesta abordagem, revelam problemas impostos à gestão monetária do Estado, porque explicitam, a partir de uma definição marxista do dinheiro como relação social, a fuga diante da moeda nacional e o enfraquecimento ou perda de seu reconhecimento social como equivalente geral. Esta perda de reconhecimento é, ademais, bem apreendida por Minsky quando destaca que "qualquer pessoa pode criar dinheiro, o problema é conseguir que ele seja aceito (Minsky, 1986, p. 228). Para a MMT, porém, esse limite parece não se constituir em problema para a moeda criada pelo Estado. Sustentam, a esse respeito, que " 'taxes drives money': if a sovereing has the power to impose and enforce a tax liablility, it can ensure a demand for its currency" (Wray, 2012, p. 53). Neste sentido, o Estado passa a assumir ele mesmo também o poder de garantir a aceitação da moeda por ele criada.

Neste ponto, é preciso destacar que mesmo o Estado emissor da moeda internacional enfrenta limites, ainda que menores, no que se refere ao seu poder monetário. Tais restrições se impõem por 
meio dos conflitos provocados na sua gestão entre os próprios agentes privados do país emissor, beneficiados ou prejudicados com a evolução do valor da moeda. Se, por exemplo, o dólar se valoriza, prejudica exportadores. Se, ao contrário, se desvaloriza, prejudica importadores e credores. Isso limita o poder do Estado nacional que emite a moeda internacional, demostrando que, mesmo neste caso, torna-se necessário garantir que a moeda emitida cumpra o papel de equivalente geral que o dinheiro deve ter.

Portanto, a partir da análise aqui exposta, os limites da gestão monetária do Estado existem em graus diferenciados para todos os Estados nacionais - sejam eles de países menos desenvolvidos cujas moedas são inconversíveis, sejam eles países mais desenvolvidos com moedas conversíveis, seja ele o Estado nacional emissor da moeda internacional, como é o caso do dólar. Temos, assim, como detalharemos em seguida, um papel monetário do Estado bem mais limitado do que o apresentado pela MMT, modelo analítico no qual o Estado garante não apenas o crescimento do produto e do emprego, mas é potente ainda para regular o valor da moeda.

Para os teóricos da MMT, esses limites não existem ou não precisam existir para a maior parte dos Estados nacionais, dado que governos soberanos são os que criam sua própria moeda. Apenas os países que adotam taxas fixas ou administradas de câmbio não são soberanos, uma vez que "a government that promises to convert its own currency on demand and at a fixed exchange rate is constrained by its ability to obtain that to which it promises to convert" (Tymoigne; Wray, 2013, p. 2). Nesse sentido, são financeiramente constrangidos. O contrário ocorre com os países que adotam taxas flexíveis de câmbio, independentemente do seu grau de desenvolvimento econômico e poder político.

A conceituação do papel monetário do Estado na abordagem marxista, ao contrário, assume que há hierarquias entre as moedas e que, para reproduzir-se como tal, o equivalente geral precisa se submeter a um processo complexo e dinâmico de sanção social. Isso envolve a ação estabilizadora do Estado, ancorada no poder econômico e político nacional que ele representa, razão para a hierarquia entre as moedas, mas também a sociedade como um todo, ao participar do processo de produção, circulação e distribuição, aceitando ou rejeitando a moeda nacional ao longo deste processo (perpassado, naturalmente, pela luta entre as classes).

A conversibilidade geral entre mercadorias e formas de dinheiro, sob pena deste perder seu reconhecimento social, demanda certa (ainda que não plena) proporcionalidade, revelando, desse modo, o caráter relativo da autonomia entre preços e valores, e, assim, a necessidade da preservação da lei do valor em última instância - o que possibilita que "o símbolo do valor [dinheiro] mantenha certa ligação com o valor que ele supostamente representa" (Mollo, 1991, p. 54). O reconhecimento do dinheiro não está sustentado, por isso, em nenhum valor intrínseco, mas em sua capacidade de possibilitar o andamento da reprodução e acumulação de capital.

Torna-se evidente, assim, que esse processo social é também político e ideológico, não podendo ser concebido como estritamente "econômico" - algo que já figura implícito, ademais, nesta apresentação do "tateamento social" entre valores e preços, da reprodução complexa do equivalente geral como validador social do trabalho empenhado na produção de mercadorias e da restrição monetária como imposição irregular e, em última instância, da lei do valor. A existência e reprodução continuada do dinheiro, particularmente sua aceitação social, encontram-se também apoiadas em 
relações político-ideológicas garantidas, sancionadas e geridas pelo Estado - um poder, como se viu, ao mesmo tempo autônomo e submetido ao conjunto da sociedade. O dinheiro não é logicamente, então, nem apenas uma criatura do mercado nem do Estado, ou seja, conta com um papel significativo do Estado embora limitado pela influência que os demais participantes da sociedade têm na dinâmica monetária.

A coerção ou restrição monetária (contrainte monétaire) significa, como vimos, a necessidade de reprodução adequada do dinheiro como equivalente geral para toda a produção mercantil. O dinheiro nunca é, portanto, conforme sustenta Brunhoff (1978a), um simples instrumento de classe, ainda que seja administrado no interesse de uma dessas classes, e mesmo que tenha objetivamente o efeito de dissimular as relações de produção. "Na contradição imanência/exterioridade do Estado em relação à sociedade de classes e à infraestrutura, o aspecto dominante é ora a imanência, ora a exterioridade (no caso da moeda, ora a gestão, ora a sanção política)" (Brunhoff, 1978a, p. 14). Isso significa dizer que, apesar de ser continuamente chamado à gestão/sanção do dinheiro, o Estado não tem poderes plenos sobre este, dado que

a decisão política governamental referente ao valor da moeda nacional - assim como as condições da reprodução dessa - é "sobredeterminada" política e socialmente. O que não é surpreendente caso se admita, por um lado, que a moeda é uma relação social, ainda que não se apresentando como tal, e, por outro, que uma intervenção política só é finalmente interpretável se relacionada com contradições econômicas e sociais determinadas (Brunhoff, 1978a, p. 171).

Uma vez que a eficácia da ação estatal nesse particular é limitada, é possível concluir que o Estado se mostra necessário, mas não pode resolver, por si mesmo, as agudas contradições do capitalismo, atuando para movê-las (também por meio da ação concernente ao dinheiro) no tempo e no espaço, de um setor a outro, de uma região a outra, e assim por diante ${ }^{15}$. Por isso, a gestão da força de trabalho e do dinheiro levada a cabo pelo Estado muda ao longo da história do capitalismo, assumindo modalidades distintas, mas nem por isso deixa de estar menos ligada à fórmula geral do capital em todos esses momentos ${ }^{16}$.

Tal limitação relativa e relacional do poder monetário do Estado acha-se ausente nas análises da MMT. Ao contrário, não apenas o Estado pode criar e cria moeda para financiar suas despesas, como pode garantir sua aceitação ao exigir o pagamento de impostos, bem como determinar seu valor e incorrer em déficits para garantir o crescimento e o emprego. Daí Wray (1998, p. 75) afirmar que "most of the pressures that government currently believe arise from international markets are actually self-imposed constraints that arise from a misunderstanding of the nature of government deficits". Diz ainda que:

Until full employment is reached, deficits can be increased to allow incomes to rise and generate more net saving. Once full employment is reached, additional deficit spending will generate additional income that is likely to cause inflationary pressures - except in the unlikely case that

(15) Conforme Roberts (2019), o Estado pode criar dinheiro, mas não pode determinar seu valor.

(16) De acordo com Mollo (2001, p. 371): "Tanto no caso da intervenção sobre a força de trabalho quanto no caso da moeda, a ação estatal apesar de sempre necessária em vista das contradições mencionadas, modifica-se ao longo do tempo e atende a necessidades históricas específicas. Assim, se em períodos como os do pós-guerra ela se pautou por intervenção maciça em investimentos e em evolução de crédito farto, para financiá-lo, o liberalismo atual não nega a necessidade de ação estatal, mas, ao contrário, sua retirada da economia é também estratégica do ponto de vista da acumulação". 
all additional income represents desired net saving. Beyond full employment, then, any further reduction of taxes or increase of government spending (increasing deficit spending) is likely to reduce the value of money as prices are bid up (Wray, 1998, p. 84).

Também Keynes (1996, 1983a, 1983b) chamava atenção, com razão, para o fato de que o aumento da demanda do governo, mesmo que com déficit, poderia compensar a deficiência de demanda provocada pela preferência pela liquidez (que inibe o investimento e o crescimento da renda e do emprego). Veremos, a seguir, como a visão dos limites ao poder monetário do Estado aqui apresentada leva a uma interpretação diferente quanto ao papel econômico deste, mesmo concordando com a possibilidade e a necessidade da ocorrência de déficits públicos. Em particular, analisaremos tais limites de ação do Estado no caso das moedas periféricas e no caso das dificuldades impostas ao papel estatal de empregador de última instância.

\section{Os limites do papel monetário do Estado: moedas periféricas e o Job Guarantee}

\section{a. Os constrangimentos impostos às moedas internacional e periféricas}

Precisamente porque o dinheiro é, como se viu, a encarnação da riqueza abstrata ${ }^{17}$, a qual não está sujeita a limites imanentes, ninguém nunca terá quantidade suficiente dele a sua disposição. A incorporação autônoma de "valor", por meio da qual a socialização econômica da produção de mercadorias é realizada, torna-se, ela mesma, o fim principal da atividade econômica capitalista: o comércio e a produção devem gerar continuamente, e a qualquer custo, novas somas de dinheiro.

Com Mollo (1998) e Lapavitsas e Saad-Filho (2000), podemos dizer que o dinheiro em Marx é endógeno - endogeneidade aqui entendida como o que, de forma intrínseca, interior ao sistema produtivo, afeta a gestão/oferta de dinheiro, ou, de outro modo dito, o postulado de que a oferta monetária é uma função da demanda por dinheiro (as necessidades da produção e da circulação determinam a quantidade de dinheiro circulante). Isso pode ser constatado ao levarmos em conta que, para Marx, o dinheiro surge da própria lógica do processo de produção das mercadorias, como fruto das determinações da mercadoria - mais especificamente da contradição privado-social que a caracteriza e que precisa, como vimos, do dinheiro para ser movimentada. Mostra-se, ainda, em sua função de meio de entesouramento, ao funcionar como canal adutor da circulação, e na ideia de que a oferta de crédito é resultado das pressões de demanda que surgem do ritmo de negócios. Em todas essas argumentações, Marx demonstra que a oferta de dinheiro é endógena; como, ademais, para a heterodoxia monetária em geral, inclusive a pós-keynesiana.

A endogeneidade da moeda, avaliada de acordo com a visão marxista, configura, então, uma das formas de se verificar o limite do poder monetário do Estado, seja para gerir a circulação (tanto do ponto de vista da quantidade de moeda quanto de seu valor), seja para operar a política monetária de forma sempre eficiente ou "precisa". Esta endogeneidade está presente também na concepção póskeynesiana, dada a preferência pela liquidez, que foge ao controle das autoridades monetárias. Tais limites não aparecem com a devida clareza, no entanto, na percepção da MMT, uma vez que, para esta, cabe ao Estado, conforme já mencionado, definir o valor da moeda e controlar ou regular a

(17) "O dinheiro é só a forma, travestida de objeto, que consegue traduzir a vocação de universalidade e infinidade do capital, seja porque prescinde das chamadas relações pessoais de dependência, seja porque derruba barreiras espaciais e temporais” (Paulani, 1992, p. 191). 
economia para compensar seus movimentos deflacionários e inflacionários. Faz isso usando da política físcal - e não da política monetária, conforme postulado pelos demais pós-keynesianos - por meio de gastos e déficits, que ampliam a oferta de moeda, e de tributos e superávits, que drenam a quantidade de moeda em circulação ${ }^{18}$.

Observe-se, porém, que Wray percebe, de certa forma, os problemas envolvidos para o controle da dinâmica monetária no caso das moedas periféricas quando trata dos títulos de dívida pública e da necessidade de vendê-los. Para a MMT, é uma ilusão pensar que os governos vendem títulos para financiar seus gastos, já que eles o fazem gastando e colocando em circulação a moeda que emitem. Vendem títulos, então, para reduzir o excesso de reservas, a curto prazo, "to prevent a Fed funds market break" (Wray, 1998, p. 86). Wray afirma que só há um caso em que o mercado força o governo a emitir títulos denominados em moeda estrangeira: quando o governo precisa comprar algo que não é produzido domesticamente. Neste caso, não pode criar a moeda desejada pelos vendedores nem fixar o preço a pagar na própria moeda.

The government may have little influence over the foreign-currency price at which the bonds will sell. It will have to obtain additional foreign currency in the future to service the debt. ... In this one case, the austerity can be at least partially blamed on 'market discipline' (Wray, 1998, p. 88).

Na verdade, essa análise de Wray se deve ao fato de o dólar, uma moeda nacional, cumprir a função de moeda internacional, conforme já mencionado. Em escritos posteriores, no entanto, esses limites aparecem ainda mais reduzidos, restringindo-se aos países que têm câmbio fixo ou administrado (Tymoigne; Wray, 2013). Diversamente, a ideia de restrição monetária aqui discutida impõe mais do que tais limites, porque os impõe, ainda que em menor medida, também ao país emissor da moeda internacional, conforme apontado anteriormente.

Sabemos que os sistemas monetários contemporâneos estão baseados em duas formas principais de moeda: o papel inconversível emitido pelo Banco Central e a moeda de crédito produzida pelos bancos comerciais. O primeiro cancela qualquer débito e pode ser usado para pagar impostos, o último é composto pelos passivos de instituições financeiras privadas (incluindo depósitos e notas bancárias), que oferecem direitos sobre outras formas de moeda. Desse modo, a quantidade e o valor de troca desse dinheiro de crédito são regulados indiretamente pela antecipação do crédito e pelo pagamento das dívidas (algo submetido aos processos de produção e acumulação), mas também, em outro nível, pela influência e a ação do Banco Central sobre as operações do sistema financeiro. Passemos a analisar, em mais detalhes, o que isso significa para uma leitura das tensões entre dinheiro, Estado e poder.

Vimos que as mencionadas moedas bancárias privadas de crédito pedem, para que sejam aceitas em circuitos ampliados, certa socialização, ou "validação social". Trata-se de um processo que é efetuado justamente por meio de uma centralização pública. "A 'gestão estatal da moeda', indispensável, consiste notadamente em abastecer os bancos secundários com moeda central a um

(18) Embora não seja objetivo deste artigo comparar a visão da MMT com a teoria pós-keynesiana em geral, mencionamos o papel menos importante, para a MMT frente à teoria pós-keynesiana, da preferência pela liquidez (chamada, no texto de Wray, de "poupança líquida"), o que leva à construção de uma análise em que não ficam propriamente claros os limites da política monetária em situações de preferência pela liquidez. 
preço que é a taxa de juros monetária" (Brunhoff, 1991, p. 138). "Sem uma intervenção central, as moedas privadas poderiam ter diferenças de cotação entre si, conforme a situação de seus emissores" (Brunhoff, 1991, p. 140), contradizendo a necessidade de uma unidade de conta (algo que ocorreu, por exemplo, nos EUA do século XIX, antes da instituição do Federal Reserve). Uma vez instituída a emissão por um Banco Central e, assim, a conversibilidade de todas as demais moedas entre si contra aquela emitida centralmente, as inúmeras moedas bancárias privadas acabam por se tornar homogêneas, e aquele "meio de pagamento, criado na relação de crédito entre um banco e um emprestador, é validado como elemento do "equivalente geral"' (Brunhoff, 1991, p. 140). Por isso é que

a emissão de moeda central não é uma intervenção estatal artificial num determinado mercado, ela faz parte das condições de funcionamento desse mercado. Da mesma maneira que não há mercadorias sem moeda, não há moedas de créditos privados sem moeda central (Brunhoff, 1991, p. 142, grifos da autora).

O dinheiro capitalista, pensado de modo unitário, está assentado, então, em dois componentes: um privado, a moeda dos bancos, e outro público, a moeda do Banco Central. Em qualquer caso, esse mecanismo nos ajuda a entender, uma vez mais, porque o dinheiro é endógeno. O Estado, via Banco Central, não "cria" direta e impunemente a moeda, mas o faz sancionando socialmente sua criação.

Seja qual for a conjuntura, o mercado monetário entre bancos emprestadores e tomadores de reservas ("fundos federais", contas correntes dos bancos junto ao Banco Central) é normalmente o lugar onde se exprimem as necessidades dos bancos em moeda central. [...] Essa gestão de pagamentos difere das operações de socorro que disfarçam as fraquezas dos grandes bancos, mas também faz o Banco Central intervir como emprestador em última instância. Ele ratifica, a custo variável, uma criação de moeda da qual ele não é o estimulador. Suas intervenções não podem suscitar o crédito privado, que depende principalmente das relações entre bancos e empresas: não é "dinheiro fácil" que está na origem do crescimento econômico, ele nada mais faz que acompanhá-la e favorecê-la. Inversamente, uma restrição poderosa do refinanciamento dos bancos pelo Banco Central não provoca a crise econômica, mas a cristaliza (Brunhoff, 1991, p. 145, grifos da autora).

Isso significa, conforme aponta Belluzzo (2013, p. 61), que nas economias mercantis capitalistas, o dinheiro - como forma geral da riqueza - é simultaneamente um bem público e objeto de desejo privado. Nessa condição de "bem público", é referência para todos os atos de produção e troca de mercadorias, bem como para mensuração da riqueza. É por isso que deve estar sujeito a normas de emissão, circulação e destruição que sustentem e reafirmem de modo continuado sua universalidade como padrão de preços, meio de circulação e forma geral da riqueza ${ }^{19}$.

(19) Mas "para reafirmar, continuamente a sua universalidade e a unidade das três funções o dinheiro não pode ser produzido privadamente, nem qualquer decisão privada pode substituí-lo por outro ativo. Ou seja, em uma economia mercantil capitalista nenhum agente privado tem a faculdade de comprar mercadorias, pagar suas dívidas ou avaliar seu patrimônio com moeda de sua própria emissão. Isso significa que as expectativas de receita, os cálculos de custos e preços, os direitos aos rendimentos do trabalho e dos ativos instrumentais, o valor das dívidas e a avaliação do estoque de riqueza real e financeira são 'declarações', ideia de quanto pretendem valer, em termos do 'equivalente geral'. Mas essas declarações só podem ser reconhecidas 'socialmente' quando acontece o 'salto mortal' das mercadorias e dos ativos privados, a sua metamorfose na forma geral da riqueza” (Belluzzo, 2013, p. 61). 
Disso resulta o processo de "centralização conflituosa", nas palavras de Brunhoff (1985, 1991), levado a cabo na relação entre bancos secundários e o Banco Central, dinâmica que assume formas concretas variadas em relação às ações governamentais concernentes ao papel do Banco Central como emprestador de última instância. Assim sendo, se existem, em um dado momento, vários tipos de "moedas" em circulação em uma esfera nacional, é preciso que o Estado garanta sua condição ou "qualidade" monetária de alguma maneira - o que ocorre, como se viu, na medida em que essas são conversíveis na moeda pela qual o Estado é responsável direto. Havendo vários Estados, é preciso, ainda, que se verifique também, de algum modo, certa conversibilidade entre as moedas nacionais. Isso supõe a existência uma moeda internacional de referência, posta em circulação segundo regras de gestão "acordadas" pelos Estados ou impostas a eles.

Essa descrição mostra, então, que a restrição monetária se verifica na relação entre o Estado e os agentes econômicos, mas também em uma economia internacional, entre os diferentes Estados nacionais. Há, assim, uma hierarquia de moedas, em que temos, inicialmente, a moeda bancária, que é uma moeda privada, e que precisa ser convertida em moeda nacional; um segundo nível, onde a moeda nacional aparece com seu caráter público superior; e o terceiro nível, o da moeda internacional na qual as moedas nacionais precisam ser convertidas.

A dificuldade dos países periféricos, nesse particular, se dá na medida em que suas moedas não são facilmente conversíveis nas demais, justamente porque não estão lastreadas em igual poder econômico (e político). Precisam de recursos externos, mas não podem obtê-los por meio de meras operações de compra e venda de bens e serviços, dada a natureza do que neles é produzido. Precisam comprar fora porque não produzem domesticamente o que lhes é necessário. A maior parte de seus ganhos tecnológicos depende dos países centrais. Suas dívidas são denominadas nas moedas de outros países e nelas precisam ser pagas, o que requer a necessidade permanente de obtê-las - algo que não ocorre sem problemas e dificuldades. Assim, a entrada e saída de recursos externos fica, de certo modo, à mercê dos interesses destes países, a não ser quando o Estado assume o controle regulatório neste campo.

Neste último caso, porém, por maiores que sejam as vantagens de tal regulação contra deixar a situação ao sabor do mercado, as dificuldades não são pequenas, o que mostra os limites de algumas moedas, e o seu poder inferior na hierarquia monetária.

De um lado, é correto, como sustentam Aglietta e Orléan $(1990,2002)^{20}$, que o dinheiro é fruto de uma violência fundacional que garante a coesão social das sociedades mercantis, como um momento decisivo do processo de socialização. De outro, a confiança, sem dúvida, joga um papel importante na reprodução tanto econômica quanto política do equivalente geral - confiança aqui compreendida como fenômeno social. Isso porque a aceitabilidade do dinheiro pelos agentes sustentase na pressuposição de que todos os demais estarão dispostos a aceitá-lo, na rodada seguinte, como forma geral da riqueza e de existência do valor das mercadorias ${ }^{21}$. Novamente, o poder econômico

(20) Apesar desses autores, conforme critica Brunhoff (1979), abandonarem a teoria do dinheiro e do valor de Marx, substituindo a exploração de classe por uma noção de "poder como dominação", há algo de importante - e a nosso ver complementar - a ser retido nessas contribuições.

(21) No debate brasileiro recente, essa questão foi abordada por Terra (2019). 
lastreia a confiança e o reconhecimento social das moedas, de forma hierárquica, conforme o critério de conversibilidade.

Assim, como vimos anteriormente, a moeda pode ser criada pelo Estado, mas precisa ser aceita e reconhecida como equivalente geral pelo conjunto da sociedade, algo que não ocorre sem problemas, em particular, no caso das economias periféricas. Em primeiro lugar, a criação de moeda pode ser feita pelo Estado, mas a garantia de sua demanda pode ser obstada pelas dificuldades políticas postas à imposição dos tributos. Além disso, a perda de confiança na moeda pode levar à fuga diante dela e à busca pela liquidez superior oferecida pela moeda internacional, o que ameaça $o$ poder monetário do Estado. Mesmo com a possibilidade, aventada pela MMT, do controle de capitais (Wray, 2012), isso dificulta e compromete a política econômica de maneira geral, ameaçando o próprio poder do Estado afirmado pela MMT. É o que se percebe por trás das discussões sobre as dificuldades impostas às moedas periféricas, ou aquelas que se situam em nível mais baixo na hierarquia monetária internacional.

A assimetria monetária decorrente desta hierarquia de moedas conduz a uma maior vulnerabilidade das moedas periféricas (Prates, 2005). A necessidade de moeda internacional, por um lado, limita as políticas monetárias internas, uma vez que a taxa de juros é usada para atrair ou impedir a saída de capitais externos. Por outro, essa assimetria é responsável por maior entrada de capitais em períodos de bonança e farta liquidez internacional, e maior saída de capitais em períodos de problemas e queda da liquidez disponível, levando as economias periféricas a ciclos reflexos dependentes do que ocorre no exterior (Resende; Amado, 2007).

Tais dificuldades se relacionam com a inconversibilidade das moedas periféricas. Os autores ortodoxos (Arida, 2003) costumam associar a baixa conversibilidade dessas moedas à limitação imposta aos mercados, ou à de falta de liberdade ao movimento de capitais que imporia um prêmio adicional sobre a taxa de juros, em função do temor de políticas que limitem ou criem entraves à conversibilidade. Porém, como destacam Belluzzo e Carneiro (2004, p. 220), a fraqueza ou inconversibilidade das moedas periféricas são de ordem "genético-estruturais". Conforme apontam, "a demanda por divisas é função dos estoques de riqueza e dívida" (Belluzzo, Carneiro, p. 221). Tratase, pois, de confiança na moeda que depende de fatores objetivos ligados, conforme tratamos anteriormente, ao poder econômico. Do poder econômico depende, então, a maior facilidade ou dificuldade para garantir não apenas a conversão das mercadorias em dinheiro, mas também a conversibilidade das moedas em equivalente geral e, no limite, a reprodução da própria moeda internacional em equivalente geral - algo que também não se dá sem problemas.

Em relação a tais conflitos, cabe adicionarmos, finalmente, que se é possível falar, em sentido amplo, em mecanismos de violência e confiança na reprodução do dinheiro como equivalente geral, isso não ocorre senão no interior do movimento de luta entre as classes - um conflito produtivo e distributivo no qual a administração do dinheiro ocupa posição privilegiada. É dessa luta que trataremos a seguir, discutindo o estoque regulador de emprego ou o papel de empregador em última instância proposto pela MMT.

\section{b. As dificuldades impostas ao estoque regulador do emprego}

Vimos que o capital como relação social de exploração objetivada na extração de mais valia pressupõe o assalariamento vinculado ao apartamento dos trabalhadores em relação aos meios de 
produção. Sabemos, ainda, que o Estado moderno intervém, antes, no processo de acumulação primitiva, por meio da violência originária que possibilita, de um lado, o surgimento do proletário, e, de outro, do capitalista, dono do dinheiro/meios de produção ${ }^{22}$; mas intervém também, depois, na sanção de regras e normas que impõem ao conjunto dos capitalistas uma limitação da duração da jornada de trabalho, sem a qual a força de trabalho, a depender das condições para sua oferta continuada, poderia ser irreparavelmente exaurida.

Mas essa intervenção estatal sobre a força de trabalho vai além, impondo-se como necessária também devido à "insuficiência do salário direto em assegurar a reprodução desta força" (Brunhoff, 1977, p. 131). Isso porque, para além do valor médio-cotidiano da força de trabalho, há que se arcar com o custo de reprodução daquele trabalho vivo, porém desempregado - desemprego que emerge do próprio funcionamento e desenvolvimento do capitalismo, com o chamado exército industrial de reserva.

Apesar da não responsabilização direta dos capitalistas pela reprodução das condições de vida de trabalhadores desempregados, doentes, etc., sabe-se que o exército industrial de reserva ${ }^{23}$ é funcional ao rebaixamento do salário médio e também como meio de aprovisionamento de mão de obra necessária em momentos de salto ou aceleração da acumulação. É preciso, então, que essa massa de trabalhadores privados de seus meios de existência, o exército de reserva, seja mantida, de tal modo que a força de trabalho (em forma de mão de obra barata) esteja sempre à disposição e os salários não cresçam continuamente. Trata-se de garantir, em suma, ao mesmo tempo, a disciplina do trabalho e a insegurança do emprego.

É aí que intervêm as instituições não-capitalistas [não orientadas para o lucro], de caráter mais ou menos estatal, que asseguram a reprodução da força de trabalho, dentro dos limites da manutenção de uma insegurança fundamental do emprego e através de formas que garantam a disciplina do trabalho (Brunhoff, 1985, p. 8).

Desse modo, "são as próprias contradições definidoras do modo de produção capitalista que supõem uma ação estatal na gestão da força de trabalho, neste caso proporcionando formas de assistência, previdência e seguridade sociais" (Mollo, 2001, p. 370). Mas a gestão da força de trabalho não pode ser diretamente realizada, segundo Brunhoff (1985), por nenhuma das classes imediatamente interessadas nesta, algo que levaria à introdução de "práticas de classe", em choque com o objetivo restrito e necessário de assistência/previdência. É por isso que, mesmo quando os

(22) No tocante ao objeto mais específico desta discussão, cabe nos atentarmos para passagem de Marx (2013, p. 824-825) sobre a relação, mediada pelo Estado, entre acumulação primitiva, dívida pública e dinheiro: "A dívida pública torna-se uma das alavancas mais poderosas da acumulação primitiva. Como com um toque de varinha mágica, ela infunde força criadora no dinheiro improdutivo e o transforma, assim, em capital, sem que, para isso, tenha necessidade de se expor aos esforços e riscos inseparáveis da aplicação industrial e mesmo usurária. Na realidade, os credores do Estado não dão nada, pois a soma emprestada se converte em títulos da dívida, facilmente transferíveis, que, em suas mãos, continuam a funcionar como se fossem a mesma soma de dinheiro vivo. (...) a dívida pública impulsionou as sociedades por ações, o comércio com papéis negociáveis de todo tipo, a agiotagem, numa palavra: o jogo da Bolsa e a moderna bancocracia. Desde seu nascimento, os grandes bancos, condecorados com títulos nacionais, não eram mais do que sociedades de especuladores privados, que se colocavam sob a guarda dos governos e, graças aos privilégios recebidos, estavam em condições de emprestar-lhes dinheiro".

(23) É importante lembrar, conforme Marx (2013), que o exército industrial de reserva surge de um processo normal, inerente ao funcionamento capitalista, uma vez que é fruto da busca pelo aumento do lucro via aumento da mais-valia relativa, com introdução de inovações tecnológicas que, por buscarem o aumento da produtividade da força de trabalho, são poupadoras de mão de obra. 
mecanismos e aparatos de gestão da assistência, previdência e seguridade sociais são concedidos à iniciativa privada, tais funções devem permanecer ligadas indiretamente ao Estado; uma vez que não podem ser transferidas para os próprios operários (mais carentes), tampouco arcadas pelos capitalistas sob consequência de redução de seus lucros ${ }^{24}$.

Neste sentido, o estoque regulador de emprego proposto pela MMT - ou o papel de empregador em última instância (Wray, 1998) - nada mais é do que parte desta gestão estatal da força de trabalho, tal como o são a previdência e a assistência social. Contudo, essa política enfrenta constrangimentos que refletem os limites do poder do Estado frente a problemas que são inerentes ao capitalismo ${ }^{25}$.

Segundo Wray (1998), é possível atingir o pleno emprego - entendido como a contratação de todos os que aceitarem o salário fixado pelo governo - e criar um estoque regulador de trabalhadores a ser conduzido conforme objetivos de política econômica. Tal proposta é o que permite associar mais particularmente Minsky e Keynes à MMT, como faz Wray (1998). Isso também é analisado por Kalecki, mas a partir de definições de moeda e políticas fiscal e monetária distintas ${ }^{26}$.

Para Minsky (1986, p. 308), é possível (e desejável) a criação de uma estratégia de política econômica de pleno emprego ou um estoque regulador de emprego (ELR, na sigla em inglês) que não conduza à inflação nem à deflação: "since only government can divorce the offering of employment from the profitability of hiring workers, the infinitely elastic demand for labor must be created by government". Também para Kalecki (1943, p. 1),

If the government undertakes public investment (e.g. builds schools, hospitals and highways) or subsidizes mass consumption (by Family allowances, reduction of indirect taxation or subsidies to keep down the prices of necessities), and if, moreover, this expenditure is financed by borrowing and not by taxation (....) the effective demand for goods and services may be increased up to a point where full employment is achieved.

A proposta da MMT vai na mesma direção. A ideia aqui é que o governo contrate todo trabalhador desempregado que esteja disposto a trabalhar pelo salário por ele fixado. O salário é fixado, então, de maneira exógena, pelo governo, e em torno desse salário o ELR flutua. Segundo Wray, por um lado, isso amplia o déficit público, já que o estoque regulador será por ele financiado,

(24) Ainda de acordo com Brunhoff (1985), outra forma de entender essa questão é pensar no caso específico dos fundos previdenciários, que, segundo ela, devem ser geridos diretamente pelo Estado: transferidos aos trabalhadores assalariados, poderiam financiar diretamente seus interesses imediatos (sindicais, por exemplo), entregue aos capitalistas, buscariam com estes ampliar seu lucro, aprofundando a exploração dos trabalhadores. Em ambos os casos, estaria desvirtuada sua finalidade original, ou seja, a manutenção da força de trabalho desempregada.

(25) Tais limites não impedem, ou de todo inviabilizam, caso se queira, uma defesa política de tais proposições - já que estas podem, a depender das condições, configurar uma via para melhor inserir o trabalhador na relação capital-trabalho. Ao contribuírem para um avanço objetivo na situação material dos trabalhadores no presente, podem favorecer sua organização para um enfrentamento da luta de classes em nível superior, em prol de outro modelo de sociedade (Mollo, 2001). Em qualquer caso, a análise crítica dos limites mencionados contribui para o bom desenho da política, caso este seja o objetivo, e, ademais, para bem apreendermos necessidades que vão para além dela.

(26) Por razões de escopo, essas diferenças não serão aqui discutidas. Cumpre apontar brevemente que para Wray, como vimos, a moeda é criada para financiar gastos do governo e é aceita para pagar tributos. A criação de moeda depende, pois, da política fiscal, enquanto a política monetária encarrega-se de fixar a taxa de juros que, segundo ele, "only very indirectly affects the quantity of Money" (Wray, 1998, p. 97). Esta é uma visão diferente da de Keynes, bem como das de Minsky e Kalecki. 
e, por outro, pode levar à inflação, uma vez que ampliará a demanda. De forma a evitá-la, propõe-se que "the size of the deficit spending necessitated by ELR intervention will be 'market determined' by the desired net nominal saving position of the public" (Wray, 1998, p. 130). Ou seja, o estoque regulador funciona reduzindo o "exército industrial de reserva", conforme definição de Marx, o que eleva os salários. No entanto, o ELR conta com um estoque de trabalhadores que pode ser usado para contratação a salários relativamente baixos. Isso atua, conforme destaca o próprio Wray (1998), de modo a conter os aumentos salariais - uma vez que trabalhadores mais bem remunerados são substituídos pelos trabalhadores fornecidos pelo estoque ELR.

Como política econômica expansionista, o ELR funciona conforme previsto e sugerido por Keynes e pelos pós-keynesianos, já que o aumento da demanda e do emprego entra nas expectativas dos potenciais investidores, reduz a preferência pela liquidez e eleva o investimento, promovendo outra rodada de aumento multiplicado da renda agregada e do emprego. $\mathrm{O}$ alcance deste processo, porém, nos traz de volta aos limites postos ao dinheiro e ao Estado no capitalismo. Kalecki (1943, p. 2) analisa tais constrangimentos, listando três razões para a oposição dos capitalistas às políticas de pleno emprego:

(i) dislike of government interference in the problem of employment as such; (ii) dislike of the direction of government spending (public investment and subsidizing consumption); (iii) dislike of the social and political changes sustaining the maintenance of full employment.

Os argumentos para tais temores são velhos conhecidos nossos e, ao mesmo tempo, bastante atuais. Para justificar o primeiro, a ameaça de déficit público afeta a confiança dos investidores, que deixam de investir. Quanto ao segundo, a ideia é a de que mesmo que o governo não concorra no início com a iniciativa privada, há sempre o risco de o Estado exagerar com a entrada em outros ramos de negócios. Finalmente, o terceiro temor é justificado pela ideia de que é preciso "suar para ganhar o salário". Conforme destaca Kalecki (1943, p. 3), todas essas justificativas encobrem o temor de que o desemprego, como veículo de disciplinamento e controle dos trabalhadores, seja comprometido: "The social position of the boss would be undermined, and the self-assurance and classconsciousness of the working class would grow".

Observe-se que, aqui, como bem sabia Marx, o desemprego é política e economicamente importante para manter a desproteção ou insegurança do trabalhador. Na base desta necessidade de insegurança revela-se uma razão econômica fundamental, que limita a busca pelo pleno emprego no capitalismo, a ser: à medida que o desemprego cai, aumentam os salários e reduzem-se os lucros, objetivo basilar do sistema. Conforme sustentava Marx, é essa pressão que leva às inovações e ao crescimento da composição técnica do capital, que fazem do capitalismo um modo de produção brilhante em matéria de progresso tecnológico. Dizia Marx (2013, p. 704), a esse respeito: "o capital adicional formado no decorrer da acumulação atrai, proporcionalmente a seu volume, cada vez menos trabalhadores. Por outro lado, o velho capital, reproduzido periodicamente numa nova composição, repele cada vez mais trabalhadores que ele anteriormente ocupava". Com políticas de aumento de emprego ou sem elas, o sistema se encarrega de excluir da produção parcela significativa da população trabalhadora, tanto mais quanto maior for o objetivo de lucro e o poder de barganha dos capitalistas na relação capital-trabalho. Isso porque, como também apontava Marx (2013, p. 715), 
“(...) o mecanismo da produção capitalista vela para que o aumento absoluto de capital não seja acompanhado de um aumento correspondente da demanda geral de trabalho".

\section{Considerações finais}

Procuramos descrever, neste artigo, a concepção marxista de dinheiro como relação social vis a vis o poder monetário do Estado, contrapondo-os às ideias da MMT. Destacamos, inicialmente que, ao contrário de ser única ou fundamentalmente uma criatura do Estado, o dinheiro é uma criação social. Nesta criação, o Estado exerce importante papel monetário, já que, dado o caráter público do Estado, seu poder é hierarquicamente superior ao dos membros privados da sociedade. Mas o dinheiro emerge como obra social da exclusão de uma mercadoria para desempenhar o papel de validador social dos trabalhos privados - o que configura uma relação social. Quando deixa de ser, formalmente, uma mercadoria, o dinheiro não perde tal papel social nem pode prescindir de tal dimensão social para funcionar como tal. É isso que impõe limites ao poder monetário do Estado.

Com a moeda fiduciária, a restrição monetária torna-se mais complexa. Além da conversão das mercadorias em dinheiro, é necessário que os diferentes tipos de moeda privadas se convertam entre elas e na moeda nacional. Também as moedas nacionais precisam se converter em moeda internacional. Neste processo, o Estado tem sempre um papel hierarquicamente superior, que lhe é conferido pelo seu caráter público, diante do caráter privado dos demais agentes criadores de moedas. Mas esse papel encontra limites. O Estado pode criar moeda ou reduzir a taxa de juros para estimular a reprodução do capital, mas precisa garantir também o reconhecimento social da moeda, que depende, entre outras coisas, da aceitação desta pelos membros da sociedade, e da conversibilidade da moeda nacional em moeda internacional. Tal conversibilidade é necessária, mas nem sempre é garantida. Ela está relacionada ao poder econômico e político do Estado emissor, o que explica as maiores dificuldades e os limites mais estreitos enfrentados pelas economias periféricas. Mas mesmo o Estado nacional emissor da moeda internacional se defronta com limites ao exercer seu poder monetário. Isso porque a criação de moeda precisa respeitar o papel de equivalente geral que o dinheiro desempenha. Exageros de qualquer lado podem prejudicar grupos econômicos nacionais específicos, ou outros Estados nacionais, o que constrange a ação estatal do emissor da moeda internacional. Do exposto, é possível concluir que o caráter de relação social do dinheiro leva a um papel monetário do Estado mais complexo do que aquele apresentado pela MMT - centrado na criação de dinheiro para financiar gastos públicos que permitem gerar rendas para o pagamento dos tributos.

O Estado cumpre também um papel econômico importante na gestão da força de trabalho. Precisa garantir a sobrevivência dos trabalhadores desempregados, dado que o avanço tecnológico que aumenta a produtividade do trabalho na medida em que busca aumentar o lucro, objetivo do sistema - é poupador de mão de obra. A manutenção dos trabalhadores desempregados requer um papel estatal via de regra cumprido pela assistência e previdência sociais, e auxílio-desemprego. A contenção do desemprego, em busca de coesão social, pode ocorrer via estímulo à demanda e à produção para ampliação das contratações, e até fornecendo "empregos de última instância", como propõe a MMT. Isso, porém, não garante, nem pode garantir, no capitalismo, o pleno emprego situação em que o aumento dos salários reduziria os lucros, razão de ser deste modo de produção. 
Edemilson Paraná, Maria de Lourdes Rollemberg Mollo

\section{Referências bibliográficas}

AGLIETTA, M.; ORLÉAN, A. A violência da moeda. São Paulo: Brasiliense, 1990.

AGLIETTA, M.; ORLÉAN, A. La monnaie entre violence et confiance. Paris: Odile Jacob, 2002.

ARIDA, P. Por uma moeda plenamente conversível. Revista de Economia Política, v. 23, n. 3 (91), jul./set. p. 151-154, 2003.

BELLUZZO, L. G. M. O capital e suas metamorfoses. São Paulo: Editora Unesp, 2013.

BELLUZZO, L. G. M.; CARNEIRO, R. O mito da conversibilidade. Revista de Economia Política, v. 24, n. 2 (94), p. 218-222, abr./jun. 2004.

BRUNHOFF, S. Crise capitalista e política econômica. In. POULANTZAS, N. (Ed.). Estado em crise. Rio de Janeiro: Graal, 1977.

BRUNHOFF, S. A política monetária: um ensaio de interpretação marxista. Rio de Janeiro: Paz e Terra, 1978a.

BRUNHOFF, S. A moeda em Marx. Rio de Janeiro: Paz e Terra, 1978b.

BRUNHOFF, S. Les rapports d'argent. Grenoble: Presses Universitaires de Grenoble/François Maspero, 1979.

BRUNHOFF, S. Estado e capital: uma análise da política econômica. Rio de Janeiro: Forense Universitária, 1985.

BRUNHOFF, S. A hora do mercado: crítica do liberalismo. São Paulo: Editora Unesp, 1991.

HEINRICH, M. An introduction to the three volumes of Karl Marx's Capital. New York: Monthly Review Press, 2004.

KALECKI, M. Political aspects of full employment. Political Quarterly, v. 14, n. 4, p. 322-331, 1943. Disponível em: https://delong.typepad.com/kalecki43.pdf. Available at: 29 abr. 2019.

KEYNES, J. M. Alternative theories of the rate of interest. In: THE COLLECTED Writings of John Maynard Keynes, v. 14. London: MacMillan and Cambridge University Press, 1983a.

KEYNES, J. M. Mr. Keynes' finance. In: THE COLLECTED Writings of John Maynard Keynes, v. 14. London: MacMillan and Cambridge University Press, 1983b.

KEYNES, J. M. A teoria geral do emprego, do juro e da moeda. São Paulo: Editora Nova Cultural, 1996. (Coleção Os Economistas).

LAPAVITSAS, C.; SAAD-FILHO, A. The supply of credit money and capital accumulation: a critical view of post-Keynesian analysis. Research in Political Economy, 18, p. 309-334, 2000.

LERNER, A. Functional finance and the federal debt. Social Research, v. 10 p. 38-51, 1943. 
LERNER, A. Money as a creature of State. American Economic Review, 37, 20f, p. 312-317, May 1947.

MARX, K. Grundrisse: manuscritos econômicos de 1857-1858. São Paulo: Boitempo, 2011.

MARX, K. O Capital, v. I. São Paulo: Boitempo, 2013.

MARX, K. O Capital, v. III. São Paulo: Boitempo, 2017.

MILIOS, J. Rethinking Marx's value-form analysis from an Althusserian perspective. Rethinking Marxism: A Journal of Economics, Culture \& Society, v. 21, n. 2, p. 260-274, 2009.

MINSKY, H. Stabilizing an instable economy. New Haven, CT: Yale University Press, 1986.

MOLLO, M. L. R. A relação entre moeda e valor em Marx. Revista de Economia Política, v. 11, n. 2, p. 40-59, abr./jun. 1991.

MOLLO, M. L. R. A importância analítica da moeda em Marx e Keynes. Análise Econômica, ano 16, n. 29, p. 5-20, mar. 1998.

MOLLO, M. L. R. A concepção marxista de Estado: considerações sobre antigos debates com novas perspectivas. Economia, Niterói, Rio de janeiro, v. 2, n. 2, p. 347-389, jul./dez. 2001.

MOLLO, M. L. R. Ortodoxia e heterodoxia monetárias: a questão da neutralidade da moeda. Revista de Economia Política, v. 24, n. 3 (95), jul./set. 2004.

MOLLO, M. L. R. Valor e dinheiro nos Grundrisse: uma discussão contemporânea. In: DE PAULA (Org.). O ensaio geral: Marx e Crítica da Economia Política (1857-1858). Belo Horizonte: Editora Autentica, 2010.

PARANÁ, E. Bitcoin: a utopia tecnocrática do dinheiro apolítico. São Paulo: Autonomia Literária, 2020.

PAULANI, L. M. Do conceito de dinheiro e do dinheiro como conceito. Tese (Doutorado)-IPE, Universidade de São Paulo, São Paulo, 1992.

PRATES, D. As assimetrias do sistema monetário e financeiro internacional. Revista de Economia Contemporânea, v. 9, n. 2, p. 263-288, maio/ago. 2005.

RESENDE, M. F. C.; AMADO, A. M. Liquidez e ciclo reflexo: algumas observações para a América Latina. Revista de Economia Política, v. 27, n. 1 (105), p. 41-59, jan./mar. 2007.

RESENDE, A. L. A crise da macroeconomia. Valor Econômico, 8 mar. 2019a.

RESENDE, A. L. Liberalismo e dogmatismo. Valor Econômico, 13 maio 2019b.

RESENDE, A. L. Consenso e contrassenso: por uma economia não dogmática. São Paulo: PortfolioPenguin, 2020.

ROBERTS, M. Modern Monetary Theory - parts1 and 2. Michael Roberts Blog, 2019. 
Edemilson Paraná, Maria de Lourdes Rollemberg Mollo

RUBIN, I. I. A teoria marxista do valor. São Paulo: Editora Polis, 1987.

TERRA, F. B. Uma crítica pós-keynesiana à MMT. Valor Econômico, 3 abr. 2019.

TYMOIGNE, E.; WRAY, R. Modern Money Theory: a reply to critics. Levy Economics Institute, 2013. (Working Paper, n. 778).

WRAY, R. Understanding modern money. Cheltenham, UK/Northamption, MA, USA: Edward Elgar, 1998.

WRAY, R. Modern Money Theory - a primer on macroeconomics for sovereign monetary systems. Houndmills, Basingstoke, Hampshire: Palgrave Macmillan, 2012. 